\title{
Overview of the Release of Sanction for Workers Withdrawing the Self before the End of the Contract
}

\author{
Venia Miranda Dewi Hascaryo ${ }^{1 *}$, Solechan $^{2}$, Nabitatus Sa'adah $^{3}$ \\ \{VeniaMiranda97@gmail.com ${ }^{1}$, solechan@live.undip.ac.id ${ }^{2}$, nabitatass@ gmail.com³ \\ Fakultas Hukum, Universitas Diponegoro, Jl. Prof. H. Soedarto, S.H., Semarang, Indonesia 50275 1,2,3
}

\begin{abstract}
Imposition of sanctions is very important in the world of work. The sanctions imposed by companies on workers who resign before the end of the contract period are not all the same. Imposition of sanctions can be seen if the employee makes mistakes, violations, and even to the detriment of the company will be imposed or given sanctions and fines in accordance with what has become a regulation at Bank Mandiri and the provisions of Act Number 13 of 2003 concerning Employment. research shows that in terms of granting authority to impose sanctions on workers who resign before the end of the contract period at Bank Mandiri is in accordance with statutory regulations. Imposing sanctions for resigned workers are required to compensate in accordance with fines that have been determined in each section of work. Efforts that can be done by Bank Mandiri to obtain their rights related to workers who resign before the end of the contract period only want accountability from workers in accordance with work agreements that have been agreed and signed by workers.
\end{abstract}

Keywords: Imposition of Sanctions, Resign, Contract, PT. Mandiri Bank

\section{Introduction}

\subsection{Background}

Some entrepreneurs realize that the most important asset in a company is Human Resources (HR). Human Resources (HR) will be managed well and professionally if the demands of business progress can be carried out in a balanced manner, which can develop and grow productively [1].

According to Article 27 paragraph (2) of the 1945 Constitution which states that every citizen has the right to work and livelihood that is decent for humanity, and also has a goal that is to get everyone who works to get the job that he wants, and every person who works is able to earn enough income for himself and for the needs of his family [2].

Many people who work by binding themselves with other parties, the labor law regulates the relationship based on an employment relationship. According to Article 1 number (15) of Law Number 13 of 2003 regarding Manpower states that, "the employment relationship is a relationship between employers and workers or laborers based on work agreements that have elements of workers, wages and orders."[3]

Work relationship referred to in the Manpower Act is a work engagement sourced from the Act. The provisions of an employment agreement that are related to work or employment are not part of the law of the agreement, therefore it can be said that the provisions of the 
employment agreement are not a supplementary law. This means that the provisions of the employment agreement are forced, and therefore it must be obeyed by any party. [4] In the provisions of the Manpower Act, work agreements are divided into two namely PKWT and PKWTT.

A company, before carrying out activities that involve workers and employers, requires an employment agreement between the employer as the first party and the worker as the second party. In this work agreement, the worker or laborer must work in accordance with the provisions stipulated by the first party and under his control and power, then the employer must provide workers/laborers with an appropriate wage [5].

The relationship between employers and workers/laborers does not always go as expected. Sometimes, a dispute arises between the worker/laborer and the employer about wage issues or something that concerns the work environment so as to create a sense of discomfort at work. This is possible because humans as social creatures in interaction have similarities and differences in interests and views between one another, so that during the implementation of work relations between employers and workers or laborers it is possible to terminate employment or turnover.

Turnover is the desire of employees to leave the company because of the decisions of the employees themselves, many reasons that cause this turnover can occur include the desire to get a better job or a better position than the previous company, not comfortable working, uncomfortable in the work environment, can not or unable to work, unsuitable for work, want to find a better job, even for the family reasons. Turnover results in a lack of productivity levels in a company, because the company will suffer other losses and there will be additional costs incurred in recruiting and training new employees. However, employees who want to quit the company must meet the procedures established by the company. If employees do not meet the criteria or violate existing procedures, they will get sanctions. One company that provides sanctions or penalties related to employees who resign before the end of the contract period is Bank Mandiri.

PT. Bank Mandiri (Persero), Tbk is one of the State-Owned Enterprises (SOEs) which is engaged in banking products and services in accordance with the provisions in the legislation. Bank Mandiri was established on October 2, 1998, as part of a banking restructuring program implemented by the Indonesian government. Bank Mandiri's experience is inseparable from the long journey of 4 state-owned banks, including: Indonesia's Export-Import Bank which was established in 1824 and has been active in banking activities since 1870, Bank Dagang Negara, Bank Bumi Daya which started from De Nationale Hadelsbank NV activities until became the State Commercial Bank in 1959 and the Indonesian Development Bank began with the joining of the State Industrial Bank (BIN) which had developed economic sectors in Indonesia since 1951. In July 1999, the 4 state banks namely Bank Bumi Daya, Negara Dagang Bank, The Indonesian Import Export Bank and the Indonesian Development Bank, merged into Bank Mandiri [6].

Bank Mandiri is one company that gives authority to impose a sanction system, which has 4 bound stages, namely Class 3 months, On the Job Training (OJT) 3 months, PKWT (Specific Time Work Agreement) for 6 months, and Office Bonds for 3 year. With compensation or fines that are different and will go down each year, starting from 200 million, 150 million to 100 million.

In fact, there are still workers who want to resign from the company before the contract period ends. One of them is PT. Bank Mandiri (Persero), Tbk Head Office of Palangka Raya, Central Kalimantan. The main factor that resulted in the lack of employee performance at Bank Mandiri was a result of a fairly high turnover rate. One of them is that employees who 
work in the Marketing section feel unable to achieve the targets set by the company. The inability of employees to achieve targets set by the company can be caused by work stress.

\subsection{Formulation of the problem}

1. Does PT. Bank Mandiri (Persero), Tbk give the authority to impose sanctions on workers who resign before the end of the contract period?

2. What about legal efforts that can be done by PT. Bank Mandiri (Persero), Tbk to get their rights related to workers who resign before the end of the contract period?

\section{Method}

\subsection{Types of research}

The author uses a type of empirical legal research that is sociological legal research and can also be referred to as field research. It is studying the applicable law and what happens in reality in society [7].

\subsection{Nature of Research}

The nature of this research includes analytical descriptive research that is the research intended to describe the applicable laws and regulations that are associated with legal theories and the practice of implementing positive law regarding the above problems.

\subsection{Research sites}

The location of the study was conducted at PT. Bank Mandiri (Persero), Tbk Head Office of Palangka Raya, Central Kalimantan.

\subsection{Data source}

In this legal research the researcher uses several data sources, namely:

a. Primary data

b. Secondary Data

1. Primary Legal Materials

2. Secondary Legal Materials

3. Tertiary Legal Materials

\section{Results and Discussion}

\subsection{Authority to Impose Sanctions on Workers Who Resign Before the End of the Contract Period}

A Specific Time Work Agreement (PKWT) is a work relationship that is made based on a certain period of time or the completion of a particular job. Law No. 13 of 2003 concerning 
Manpower, stipulates that PKWT based on a certain time period can be held for a maximum of 2 years and may only be extended once for a maximum period of 1 year[8].

The maximum contract period of PKWT is 3 years. However, both parties namely the employer and the worker concerned can agree on the PKWT renewal after a grace period of 30 days from the end of the agreement. New PKWT may only be made once for a maximum period of 2 years.

If the worker resigns before the end of the contract period, then the worker is required to pay compensation to the employer in accordance with the provisions governing Article 62 of Law No. 13 of 2003 concerning Manpower which reads: "If one of the parties terminates the employment relationship before the end of the period specified in the work agreement for a certain period of time, or the termination of the employment relationship is not due to the provisions referred to in Article 61 paragraph (1), the party ending the employment relationship obliged to pay compensation in the amount of workers' wages until the deadline for the expiration of the work agreement.

Before deciding to resign, workers must first understand, study, and know the contents of the employment agreement in the company. The workers should understand whether the employment agreement a Specific Time Work Agreement (PKWT) or an Indefinite Time Work Agreement (PKWTT). If the type of agreement is PKWT, it cannot require a trial period for work, so if a PKWT contains these conditions, then the required probation period becomes null and void, if one of the parties terminates the employment relationship before the end of the period specified in PKWT, the party who terminates the employment relationship is required to pay compensation to the other party in the amount of the worker's wages until the deadline for the termination of the work agreement and the agreement with the PKWT model also does not recognize severance pay. However, unlike the PKWTT agreement, it can require a trial period of work in a maximum period of three months. During the trial period employers should not pay workers below the applicable minimum wage and the end party has the right to receive severance pay. Likewise, the company is not obliged to provide compensation. They must ensure in the employment agreement, whether there are provisions regarding the imposition of sanctions if resignation occurs in a certain period of time or not [9].

This is the same as existing regulations at Bank Mandiri, the procedure for submission of resignation must be done 30 (thirty) days beforehand to the Human Resource Department (HRD), this is in accordance with the provisions of Law No.13 of 2003 concerning Manpower. If no later than 14 (fourteen) days before the date of resignation (the last date of employment), the employer must provide an answer to the request for resignation. If the employer does not provide an answer within the 14 (fourteen) days specified, the employer is deemed to have approved the resignation according to Article 26 paragraph (3) and (4) of the Minister of Manpower and Transmigration 78/2001. Whereas for Manager, Officer employees at Bank Mandiri were conducted 3 months earlier, because this has become a regulatory requirement at Bank Mandiri Palangkaraya, this was conveyed by Budhy Nugraha Sutisna as Human Capital and General Affair Officer of PT. Bank Mandiri (Persero), Tbk Palangka Raya, Central Kalimantan [10].

Specific reasons why PT. Bank Mandiri (Persero), Tbk provides sanctions for workers who resign before the end of the contract period is to make all workers are not easy to resign from their jobs. With a variety of reasons, one of which is not comfortable working, uncomfortable in the work environment, unable or unable to work, unsuitable for work, wanting to find a better job, even family reasons. But PT. Bank Mandiri (Persero), Tbk also always provides support, support, and even gives concessions to new workers who have no 
progress for 1 month to 3 months at work, but entering in the 4th to the 6th months there must be an increase in work and separated from assistance [10].

Unlike the workers engaged in the Sales Marketing Card Officer of PT. Bank Mandiri (Persero), Tbk in the third month does not require the employee to close the sales turnover and the company still provides opportunities and encouragement to the employees of the Sales Marketing Card Officer to know, recognize and learn well how to market products to be promoted to candidates customer or customer[11].

Therefore, it can be seen from the explanation above that PT. Bank Mandiri (Persero), Tbk has imposed sanctions on workers to achieve the company's Vision and Mission which has been a guideline for all members working at Bank Mandiri, so as to create a sense of peace, comfort while working in the company. It is also one way to prevent high turnover rates, high turnover rates will have very negative impacts on companies, such as creating instability and uncertainty on labor conditions and increasing human resource costs.

\subsection{Legal Measures that Can Be Done by Bank Mandiri to Obtain Their Rights Related to Workers who resign Before the End of the Contract Period}

In a corporate environment, resignation is a common thing. This resignation is something that is not expected by the company, because it can create losses that will be experienced by the company itself, especially if the workers who resign are workers who do have good performance for the company. The company always strives to provide the best welfare for its employees to remain in the company where they work. Substitution of employees caused by resignation will complicate the company because it relates to the implementation of work programs that have been determined.

Basically, there are various reasons for someone to submit resignation, the most important and most often found in the work environment so that it can cause employees to resign or stop working that is felt never appreciated by their superiors, Workload that is not directly proportional to the amount of salary that is accepted, the company promotes the wrong people, the working atmosphere becomes unpleasant [12].

Because of that, prevention efforts to anticipate that no resignations are made by workers, among others, to be open to each other, what is meant to be open to each other is to build communication between employers and workers, this is the most important thing in a job at the company, the second reason is to invite to feel mutual ownership, one of which can be the main motivation for a worker of course the trust that has been given in carrying out his work, the third gives more rewards for the best employees, by giving rewards to the best workers it will make the workers themselves feel proud and feel valued by their superiors for the work that has been given so far.

Based on the results of interviews conducted by researchers, PT. Bank Mandiri (Persero), Tbk. Central Palangka Raya, Central Kalimantan has never extended the problem until the legal turmoil and if indeed, the problem can still be resolved by the company. Even companies have explained to new workers about the rules that apply in PT. Bank Mandiri (Persero), Tbk has a system of imposing sanctions with different fines for each work. If if there is a problem that can harm the company, then Bank Mandiri only wants the responsibility of the workers in accordance with the work agreement agreed at the beginning and the company will immediately recruit new workers who really want to work well with the company [10].

PT. Bank Mandiri (Persero), Tbk has imposed sanctions not only on workers who wish to resign before the contract period expires, but also imposes sanctions on workers who violate 
existing company regulations. For example workers embezzled company money, sexually harassed other workers, and others.

According to Article 62 of Law No. 13 of 2003 concerning Employment, the imposition of sanctions for workers who resign before the contract period expires can be subject to sanctions, ie workers who terminate employment, are required to pay compensation because they are considered to have harmed the company and will be subject to fines varying according to their work.

Whereas the imposition of sanctions imposed on workers who violate employee discipline rules can be subject to termination of employment relationship (FLE) given by the company to workers. The company can lay off if the employee violates the work agreement, company regulations or the Collective Labor Agreement (PKB), but before laying off, the company is obliged to give warning letters 3 (three) times in a row, this is in accordance with the provisions of Article 161 paragraph (1) Law No. 13 of 2003 concerning Manpower which reads:

"In the event that a worker/laborer violates the provisions stipulated in a work agreement, company regulations or collective labor agreements, the employer may terminate the employment relationship to the worker/laborer concerned, given a first, second, and warning letter. Third in a row."

The company can also determine appropriate sanctions depending on the type of violation. For certain violations, the company can issue SP 3 (warning letter three) directly or directly do the dismissal process. All of these things are regulated in work agreements, company regulations, because each company has different rules.

Not only will the sanction of Termination of Employment (PHK) be sanctioned by giving a warning letter, but workers who violate company regulations will also be subject to other sanctions in accordance with company regulations such as transfer, move an employee to a position and duties that are lower and different from his previous job. Movements can be done within the company, or sent to other areas where a company has many branches.

The second sanction is a demotion, demotion or demotion also often done by companies to employees who are considered to violate company policy. This reduction is usually done after the company has carefully reviewed it and has strong evidence that the employee must indeed be demoted.

The third sanction is revocation of allowance. The application of this type of sanction is carried out by the company if the employee receives the allowance in violation of the rules that have been jointly determined. Revocation of benefits means that an employee no longer receives supporting facilities from the company such as a car, house, etc. because the employee has not fulfilled his obligations or made a mistake by using his authority.

Other sanctions are forced to resign, employees are forced to resign by signing a resignation letter. Usually, companies do this to avoid payment of layoff compensation and the good name of employees who make mistakes will be maintained, so they can look for work elsewhere. This sanction can be called a win-win solution between the company and its employees.

Based on the explanation above, it can be seen that there are not all the same sanctions imposed by companies on workers. Imposition of sanctions can be seen if the employee makes mistakes, violations, and even to the detriment of the company will be subject to sanctions or fines in accordance with what has become company regulations and applicable laws and regulations. 
Based on the results of research that the author has done by interviewing one of the staff who have worked for 1 year at Bank Mandiri in Palangkaraya, Central Kalimantan as a Sales Marketing Card Officer named Nurul Septiyani Eka Putri, workers object to the existence of sanctions and fines that have been determined by Bank Mandiri, but over time workers feel that with the existence of these regulations workers will not violate, comply with, and will carry out existing regulations as well as possible [11].

\section{Conclusion}

Based on the data obtained, it can be concluded:

1. The company PT. Bank Mandiri (Persero), Central Tbk Palangka Raya, Central Kalimantan is given the authority to impose sanctions on workers who resign before the end of the contract period, in accordance with the provisions in Article 62 of Law No. 13 of 2003 concerning Manpower which allows workers to resign themselves before the contract period must pay compensation in accordance with fines that have been determined in each part of the work so that all the workers do not easily resign from their work. In order to achieve the company's Vision and Mission which has been a guideline for all members who work at Bank Mandiri, so as to create a sense of peace, comfort while working in the company, and in accordance with Directors' Decree No. KEP.DIR. 029/2001 dated 25 September 2001 concerning Disciplinary Regulations of PT. Bank Mandiri (Persero), Tbk.

2. . Legal remedies that can be done by employers to get their rights, related to workers who resign before the end of the contract period at PT. Bank Mandiri (Persero), Tbk. Central Palangka Raya, Central Kalimantan has never extended the problem until the legal turmoil and if indeed the problem can still be resolved by the company. The impact of civil and criminal law issues received by Bank Mandiri through the legal process is not significant, because the Bank has carried out a mitigation process carried out by the Legal Unit which is under Risk Management \& Compliance. Even, the company has already explained to new workers about the rules that apply at PT. Bank Mandiri (Persero), Tbk that it has a system of imposing sanctions with different fines for each work. If there is a problem that can harm the company, Bank Mandiri only wants the responsibility of the workers in accordance with the work agreement agreed at the beginning and the company will immediately recruit new workers who really want to work well with the company.

\section{References}

[1] W. Bangun, Manajemen Sumber Daya Manusia. Jakarta: Erlangga, 2012.

[2] S. H. Manulang, Pokok-Pokok Hukum Ketenagakerjaan di Indonesia. Jakarta: Rineka Cipta, 1988.

[3] Law Number 13 of 2003 regarding Manpower. .

[4] H. Rusli, Hukum Ketenagakerjaan Berdasarkan UU No.13 Tahun 2003 Tentang 
Ketenagakerjaan dan peraturan terkait lainnya. Jakarta: Ghalia Indonesia, 2011.

[5] S. S. Harahap, Etika Bisnis dalam Perspektif Islam. Jakarta: Salemba Empat, 2011.

[6] Bank Mandiri, "Laporan tahunan 2015."

[7] B. Waluyo, Penelitian Hukum Dalam Praktek. Jakarta: Sinar Grafika, 2002.

[8] S. Romalida, "Bagaimana Aturan Karyawan Kontrak Mengundurkan Diri Saat Jangka Waktu PKWT Belum Berakhir?," 2019. [Online]. Available: https://www.gadjian.com/blog/2019/08/28/bagaimana-aturan-karyawan-kontrakmengundurkan-diri-saat-jangka-waktu-pkwt-belum-berakhir/.

[9] KaryaOne, "Apa Saja Hal yang Harus Anda Perhatikan Selama Masa Percobaan Kerja." [Online]. Available: https://www.karyaone.co.id/blog/masa-percobaan-kerja/.

[10] Interview with Budhy Nugraha Sutisna, as Human Capital and General Affairs Office, 12 October 2019, in Semarang. .

[11] Interview with Nurul Septiyani Eka Putri, as Sales Markering Card Officer, on October 12, 2019, in Semarang. .

[12] C. Suminar, "Ini Penyebab Karyawan Terbaik 'Resign'?," 2017. [Online]. Available: https://www.kompasiana.com/cucum-suminar/56adece38e7e618515c3bac2/inipenyebab-karyawan-terbaik-resign?page=all\#sectionall. 